\title{
Editorial
}

\section{Will new planning policy guidance reduce the potential for conflict in the conservation of different elements of the UK's heritage}

\author{
Journal of Building Appraisal (2010) 6, 95-97. doi:10.1057/jba.2010.16
}

March 2010 heralds a new era in the control of planning decisions that impact directly upon the UK's heritage, following the publication of Planning Policy Statement 5 (PPS5): Planning for the Historic Environment. National government has long sought to standardise planning decisions by issue of national guidelines on the specific issues influencing planning decisions, such as the presence of elements that are of significance to the UK's heritage. Previous guidance given to planning authorities was undertaken by publication of separate specialist planning policy guidance documents (PPGs). The two main PPGs for built heritage and for archaeology were PPG15 Planning and the Historic Environment 1994, and PPG16 Archaeology and Planning 1990. If the simple logic applies that the most likely place to discover archaeological remains is around, under and within ancient buildings and settlements, then there would clearly be a potential for conflict if proposed works to an ancient building or site included excavation, even if the structural stability or future successful use of the building relied upon the completion of these works. Examples of such scenarios, like strengthening that was required to the foundations at Grade I listed York Minster, can be evidenced.

The author was watching a documentary about the work of English Heritage. Millions of pounds of public funds had been spent rescuing and repairing Apethorpe Hall in Northamptonshire. Restoration and consolidation work was being commissioned by English Heritage in order to enable the property to be sold, and was nearing completion. The sale to the right buyer who would complete the full restoration work was seen as the best chance of preserving Apethorpe as anything other than an expensive public folly, and the only way of recouping significant amounts of the public's money, which had already been spent upon it. English Heritage archaeological division entered the site on the back of geophysical survey evidence on the presumption of archaeology relating to previous development on the site, and began to dig up the lawn. The archaeologists found the house's current drainage system and the base of one off plan wall. The apparent lack of finds is not the point, but rather the action of excavating the lawn, and the potential time related consequences if they had found more evidence. Neither would be conducive to the success of the plan to secure the future of one of the nation's most important buildings, and allow large amounts of public money to be reused elsewhere (Blighty, 2010). This action although not played out in a local authority planning department, for the author epitomised the potential for conflict between those looking to the guidance of PPG15 to develop built heritage sites and those looking to discover and preserve buried heritage using guidance from PPG16. 
As previously stated in March 2010, the government published PPS5, Planning for the Historic Environment, to guide local authority in making planning decisions and in the preparation of future local development plans. For the author, a most important part of this was Annex 1 that cancels both PPG15 and PPG16 with immediate effect. As a Chartered Building Surveyor with an interest in the conservation of historic buildings, the author lamented least the demise of PPG16. With its dogmatic terms and stated presumption in favour of archaeology, it was the personal view of the author that it provided the potential to afford an unequal treatment to possible archaeology over actual at risk built heritage.

PPG16 advocated changes in design to remove a structure's footprint away from the archaeological site, so that any artefacts and remains could be preserved in situ (HMG, 1990). Design is undertaken at an early stage of the development or remediation process and is usually expensive to alter. PPG16 worked on the presumption of there being archaeology as being sufficient to trigger costly investigation (HMG, 1990). This meant that the developer was required by the planning authority at their own expense to arrange for field archaeological investigation of the site, before planning permission being considered. This delayed projects considerably and increased development costs. PPG16 stated that no local authority could trade funding for archaeological investigation against obtaining future planning permission, and no developer could expect that payment for extensive investigation be a ticket for granted planning permission (HMG, 1990). This effectively means that a developer could expend monies investigating a site for archaeological remains, could suffer the penalties having a redundant site, and possibly expensive temporary support to the historic structures, and at the end of the process find that the quality of the archaeology that was found following their own funded dig left them without the planning permissions required to continue. The terms of PPG16 were not conducive to attracting development work, which might rescue, preserve and secure the future of some important historic structures.

PPS5 is a one stop guidance document for all the UK's physical heritage. No longer is there separation between built, buried, sunken, planned or planted heritage, but just one term the 'heritage asset' (HMG, 2010). The document is much shorter than the PPG's it replaces and less dogmatic in its instructions. The need to supplement planning applications where archaeology might be presumed with desk survey and/or field evidence remains, with the caveat being that investigation need only be what is required to give the planning department enough information to understand the site (HMG, 2010). In PPS5, a heritage asset is looked at holistically and its significance assessed. Unlike PPG16, guidance now directs planners to presume in favour of the most significant elements. PPS5 advocates an evidence-based sliding scale when planners make decisions which might change or destroy elements of cultural significance.

HE9.1 Substantial harm to or loss of a grade II listed building, park or garden should be exceptional. Substantial harm or loss of heritage assets of the highest significance including scheduled ancient monuments, protected wreck sites, battlefields, grade I and II* listed buildings, grade I and II* listed parks and gardens and World Heritage Sites should be wholly exceptional. (HMG, 2010)

In an evidence-based system, using the sliding scale of importance suggested above and assisted by statutory classifications of importance, decisions should favour the most significant element, which building conservators might hope would be urgent repairs to a highly listed building over possible archaeology in the underpinning excavation site. 
There is, however, as always a caveat included that if evidence supports a possible higher class of protection than currently held, that is a site not yet scheduled but that should be, then that higher importance should be the one used (HMG, 2010).

PPS5 is, however, not a standalone document. Its concise practical guidance is supported by a much longer more prescriptive set of guidance from English Heritage, the PPS5 Planning for the Historic Environment: Historic Environment Planning Practice Guide (English Heritage, 2010). This document provides more prescriptive level of guidance to applying the doctrine of PPS5. It seems strange to the author that a document written to shorten cumbersome PPG guides should be twinned with an even more prescriptive document than the PPGs being replaced, however, the English Heritage guidebook is unlike PPS5, PPG15 and PPG16, not a direct national government publication.

The author hopes that the prospect of conflict between conservation of different elements of heritage should now be reduced, consequential to looking at them as all being potentially equal assets. Under the new guidance importance is not allocated by type of asset, but by the importance of the significance of that asset. Guidance is no longer separated into how each element of heritage should affect planning, but by planners now being guided towards adopting a more holistic approach. On first inspection as a step to reduce conflict between areas of heritage management, the author endorses the concept of PPS5, and will watch reports of future proposals to utilise and conserve built heritage in areas likely to contain buried heritage with interest.

\section{REFERENCES}

Blighty, C. (2010) English Heritage, Part one of a four part TV Documentary, UKTV, Manchester.

English Heritage. (2010) PPS5 Planning for the Historic Environment: Historic Environment Planning Practice Guide. London: Communities \& Local Government Publications.

HMG. (1990) PPG16 Planning Policy Guidance: Archaeology and Planning. London: TSO.

HMG. (2010) Planning Policy Statement 5, Planning for the Historic Environment. London: TSO.

Simon Mclean 